\title{
Katalaunská pole pohledem nejen soudobých autorů
}

\section{JAN LEPEŠKA}

Lepeška, Jan: Catalaunian Plains not only by contemporary authors

The Battle of the Catalaunian Plains was an important event in the history of Europe at the turn of Antiquity and the Early Middle Ages. It was recorded and analyzed by leading historians already in the early modern times. Among the best known we can name E. Gibson, J. B. Bury, B. Ward-Perkins, P. Heather, E. A. Thompson and others. From the Late Antiquity texts, it is necessary to highlight in particular Getica of Jordanes and information from Bishop Sidonius Apollinaris. The present text describes the historical events that preceded both the battle and the battle itself in a wider context as recorded by contemporaries themselves. The information obtained is then confronted with the conclusions of modern historians. The attention of the paper focuses mainly on the political events - relations between the Western and Eastern Roman Empire, Goths, Huns and other ethnic groups, which probably should had a major impact on the final years of the Western Roman Empire.

Key Words Catalaunian Plains; Flavius Aetius; Huns; Late Antiquity; Roman Empire doi.org/10.15452/Historica.2020.11.0007

Contact Univerzita Karlova; jan.lepeska@centrum.cz

Pro vývoj evropské civilizace představuje časové údobí poloviny 5. století významný dějinný mezník. Západní část římského impéria čelila neodvratnému vnitřnímu rozkladu a germánské kmeny, které napadaly impérium již od 2. století, se postupně usazovaly na hranicích západní části římské říše a začaly utvářet vlastní organizované státní útvary. Postupně se již nejednalo pouze o kořistníky, ale tyto útvary začaly přebírat vlivy z římského prostředí. Procházely i výraznou společenskou proměnou, na jejímž základě se začala utvářet raná středověká společnost. Do této situace zasáhlo etnikum Hunů, které bylo svým způsobem života, morálními hodnotami a kulturou zcela odlišné od ř́mské i germánské společnosti.

Roku 445 dal Attila zavraždit svého bratra Bledu a jako vládce rozsáhlého území sahajícího od Uralu po Rýn se stal postrachem křestanského světa. Jeho expanze se nejdříve obrátila směrem na Balkán, kde si roku 447 podmanil více než sedmdesát měst. Dosáhl i dalšího významného politického úspěchu, když si vynutil odstoupení římského pohraničí od Singiduna po Novae. ${ }^{1}$ Attilova moc postupně narůstala tak, jak slábl římský politický vliv. ${ }^{2}$

Z pohledu hunské opozice je třeba dodat, že ve východním impériu se uplatnila zásada o skladbě armády tvořené především z císařových poddaných. Západní část impéria však byla v tomto ohledu mnohem slabší (než část východní). O to více udivuje to, jak rychle si Attila upevnil svoji pozici.

\footnotetext{
Singidunum, dnešní Bělehrad; Novae, dnešní Svištov v Bulharsku.

2 HEATHER, Peter: The Fall of the Roman Empire : A New History of Rome and the Barbarians. Oxford 2006, s. $351-355$.
} 
Západní římská armáda byla tvořena především federáty (foederati), které Češka nazývá „spřátelenými“ germánskými kmeny. ${ }^{3}$ Přesto, že jejich reges postupně přijímali vysoké římské vojenské hodnosti, a měli představovat určitou politicko-vojenskou záruku v západním impériu, skutečnost však byla jiná. Podřizovali se císařské ravennské vládě podle toho, jak uznali za vhodné.

Západní část říše se však musela potýkat s dalším problémem, který pramenil z nejvyšších míst. Jednalo se o císaře Valentiniana III., který svojí neuváženou zahraniční i vnitřní politikou destabilizoval stát. Lze říci, že v této době byl skutečným zachráncem politické moci na západě vojevůdce Flavius Aetius. ${ }^{4}$ Mezi jeho kladné vlastnosti (které se ukázaly být jedním z rozhodujících činitelů následujícího údobí) patřilo, že netrpěl antipatiemi vůči Germánům. ${ }^{5}$

\section{Germáni}

Z pohledu germánských gentes je vhodné přistupovat k situaci z několika hledisek. Gótové představovali nejvýznamnější germánské etnikum, které zasáhlo na Katalaunských polích. Jejich historie se v první polovině 5 . století úzce váže $\mathrm{k}$ Hunům. V druhé polovině 4. století prchly čtyři gótské skupiny na území římské říše, a to ve třech různých údobích (v letech 378, 386, 405-406). Dalších šest skupin (podle mínění Heathera) zůstalo pod hunskou nadvládou (nebyly však podmaněny Huny hned najednou). ${ }^{6} \mathrm{Na}$ přelomu 4. a 5. století postupně sílilo jejich postavení. Tento trend měl počátky u náčelníka Valii. Valia podepsal s Rímem federátní smlouvu, která dala vzniknout vizigótskému „barbarskému“ státu vjižní Galii. Za vlády Theodericha I. došlo roku 421 ke konfrontaci Vizigótů (v ř́mských službách) s Vandaly. Provázanost etnik, která se utkala na Katalaunských polích, je patrná ze situace na konci 30 . let 5. století, kdy proti svým neposlušným spojencům Vizigótům Rímané nasadili pomocné sbory složené z Hunů. ${ }^{7}$

Vedle Gótů patřilo zvláštní postavení i Vandalům. Ti př́mo vojensky nezasáhli do dění na Katalaunských polích, ale jejich politické jednání (vedené náčelníkem Geiserichem) velmi ovlivnilo vývoj západní Evropy na přelomu 40. a 50. let 5. století. Dějiny Vandalů v severní Africe se pojí s rokem 429. Tehdy se Geiserich se svým vojskem (čítajícím zhruba osmdesát tisíc mužů) přeplavil přes Gibraltar a vylodil se na území rímské provincie Tingitania. ${ }^{8}$ Vandalský náčelník využil příhodného údobí, kdy byla rrímská správa v afrických provinciích oslabena vnitřními spory, a následné události, které se vyvíjely v afrických ř́mských provinciích, měly vliv i na dění na Katalaunských polích. ${ }^{9}$

V předkládaném nástinu vlivu germánských gentes nelze opominout ani Burgundy. Jejich provázanost s událostmi na Katalaunských polích spadá do 30 . let 5 . století. V té době se pokoušeli vojenskými nájezdy rozšířit svá sídla na římském území. Přestože pro následující vývoj neexistují přímá pramenná svědectví, katastrofální porážka Burgundů

ČEŠKA, Josef: Zánik antického světa. Praha 2000, s. 30.

4 Aetius byl synem prefekta pretoriánské gardy Iovia.

5 BURY, B. J.: Later Roman Empire - from death of Theodosius I. to the death of Justinian I., I. New York 1958, s. 298-299.

HEATHER, Peter: The Goths. Oxford 1998, s. 135-138.

Tamtéž, s. 105-107.

Území provincie odpovídá dnešní oblasti severního Maroka.

MITCHELL, Stephen: A History of the Later Roman Empire. Malden 2007, s. 110-112. 
od Hunů (v letech 436-437) byla hunskou spojeneckou službou západnímu impériu. ${ }^{10}$ Burgundové byli po prohraném boji velmi oslabeni a římská nabídka na uzavření nové spojenecké smlouvy jim přišla vhod. Nejvíce získali Římané. Aetius tak mohl navýšit počet spojenců Ríma. Zbylé Burgundy usadil roku 443 v údolí Rhôny nedaleko Ženevského jezera (v oblasti zvané Sapaudia) s tím, že jejich hlavním úkolem bylo bránit sapaudské území před Alamany. ${ }^{11}$

\section{Hunové}

Hunská vlna, která v 70. letech 4. století zasáhla východní oblasti impéria, byla soudobými i pozdějšími autory vnímána jako jedno velké nebezpečí, které otřáslo základy tehdejší Evropy. Voják a historik Ammianus Marcellinus (který v souvislosti s Huny nešetřil ostrými výrazy a nazýval je zvíraty, která nemají v sobě ani kousek disciplíny) chápal Huny jako velkou hrozbu civilizovanému světu. ${ }^{12}$ Podobně se vyjadřoval i Jordanes, který v Getice Huny často zahrnoval hanlivými výrazy, nikoliv však kvůli jejich chování, ale „,barbarskému“ původu. ${ }^{13}$

Velkým zlomem, který výrazně ovlivnil budoucí vojensko-politické uspořádání hunského národa, byl nástup vlády náčelníka Ruy. Ten nastoupil na počátku 20. let 5. století a stál u počátků velké hunské expanze. Nejednalo se však o jediného vládce kmenového svazu Hunů, protože se dělil o vládu se svými bratry Octarem a Mundiuchem (otcem Attily a Bledy). ${ }^{14}$

I když už v Ammianově díle lze nalézt hluboké opovržení vůči hunské kultuře a zvykům, vojenské přednosti musel Hunům přiznat i sám autor. Ammianus líčil hunské etnikum ještě na konci 4. století, kdy Hunové představovali sice silnou vojenskou sílu, ale bez jednotného velení.

Hunové neporáželi římské a gótské vojenské jednotky svým počtem, ale taktikou a vojenským zápalem. Přesto, že bylo hunské nebezpečí postupně neutralizováno znalostí jejich vojenských dovedností, je zřejmé, že jejich válečnické přednosti - spojené s nástupem Attily do čela hunského svazu - neubraly nic na jejich vojenských úspěších, které přišly zejména ve 40 . letech 5 . století. $^{15}$

V čem lze hledat vojenské úspěchy Hunů, které měly vrcholit na Katalaunských polích? Ammianus, Jordanes a Sidonius zdůrazňují ve svých dílech především zděšení z jejich vzhledu. Zejména Ammianus zdůrazňuje jejich odpudivý vzhled.

Velká část latinsky píšících autorů se shoduje i v tom, že Hunové dosáhli řady vítězství díky výborné kvalitě své bojové jízdy. Na první pohled se o ní vyjadřovali s velkým opovržením, když přirovnávají jejich koně (jako např. Ammianus), $k$ nevzhledným čtyřnohým bestiím, ${ }^{16}$ ale za tímto pohledem je patrná určitá římská obava Římanů.

\footnotetext{
THOMSON, E. A.: The Huns. Cambridge 1999, s. 36-40.

Tamtéž, s. 38-40.

12 MARCELLINUS, Ammianus: Soumrak ř́mské říše. Praha 1975, s. 443-444.

13 DOLEŽAL, Stanislav: Interakce Gótů a ř́mského impéria ve 3.-5. stoletín. l. Praha 2008, s. 222.

14 BURY, B. J.: Later Roman Empire, s. 271-274.

15 THOMSON, A. E.: The Huns, s. 62-65.

16 MARCELLINUS, A.: Soumrak, s. 443-444.
} 
Římská jízda se od hunské značně lišila. Největší rozdíly nalezneme ve zpơsobu boje, ale také ve výzbroji i v samotných koních. ${ }^{17}$ Hunští jízdní lučištníci překvapovali své nepřátele rychlostí a přesností zásahu svých šípů. ${ }^{18}$

Tato hunská bojová přednost se plně projevila ve 40. letech 5. století, kdy Hunové plenili území východního římského impéria. Hunské vojsko představovalo rychlou mobilní vojenskou údernou sílu, která mohla být v rychlém čase zmobilizována a uvedena do vojenské bojové pohotovosti (což jejich nepřátelům trvalo výrazně déle). Ammianus ve svém díle zachytil i důležitou informaci o tom, že Hunové používali železné meče, které získávali ze zdrojů porobených národů a obchodem. Římané však nezůstávali vůči hunským výhodám neteční. Hunská jízda inspirovala Římany k nutnosti osvojit si ovládání lukostřelby za jízdy. Podle historika Vegetia se této dovednosti učili od skythských lučištníků.

Ammianův náhled na Huny je však pro přiblížení katalaunské problematiky poměrně zavádějící. Problém spočívá v tom, že již na začátku 5. století využívali Římané hunských dovedností nejen po vojenské, ale i po politické stránce. ${ }^{19}$ Politicko-vojenská spolupráce západního impéria s Huny probíhala již za Stilichona. ${ }^{20}$ Tehdy hunský vládce Uldin pomohl ř́mskému vojevůdci porazit gótského krále Radagaisa. ${ }^{21}$ Hunská pozornost se posléze obrátila na jih. Mělo se jednat o kořistnickou expanzi velkého rozsahu. Hunové využili další své přednosti v podobě momentu překvapení. Mistrem tohoto tahu byl Attila. Pohled na jeho osobu se značně liší. Velká část římských historiků v něm viděla zkázu pro římský svět i pro evropskou civilizaci. Poněkud jiný názor (a nutno říci ojedinělý) zastával východořímský vyslanec Priskos, který vyzdvihoval Attilovo sídlo, které mělo civilizovaný charakter. $^{22}$

Attila po zavraždění svého bratra Bledy zahájil velké pustošivé nájezdy ${ }^{23}$ a roku 447 propukla „druhá balkánská válka“. Situace byla pro východní impérium složitá, protože v lednu došlo k velkému zemětřesení v Konstantinopoli a Attila navíc žádal východní dvůr o vydání přeběhlíků a obnovení tributu. ${ }^{24}$ Jeho plán byl ze strategického hlediska logickým řešením komplikované vojensko-politické situace, kdy bylo nejprve nutné zajistit týl, získat finanční prostředky a vojensky zabezpečit hranice s východořímskou říší. ${ }^{25}$

Hunové překročili Dunaj a zpustošili území až k Thermopylám a Konstantinopoli. Attila pravděpodobně věřil, že se doposud Římanům nepodařilo zahladit následky zemětřesení, které velmi poškodilo konstantinopolské hradby. Ty však byly (díky velkému úsilí a organizačním schopnostem prefekta pretoriánů Flavia Constantina) včas opraveny.

Východořímská říše musela ve stejné době reagovat na další hunskou agresi. Obě vojska se následně střetla v bitvě na řece Utus. Jednalo se o střetnutí, které mohlo mít (podle

\footnotetext{
17 FIELDS, Nic: The Huns - Scourge of God AD 375-565. Oxford 2006, s. 47-48.

18 BURY, B. J.: Later Roman Empire, s. 271-277.

19 SOUTHERN, Pat: The Roman army : a social and institutional history. Santa Barbara 2006, s. 245.

20 CLAUDIANUS, Claudius: Únos Proserpiny. Praha 1975, s. 93.

21 WOLFRAM, Herwig: The Roman Empire : Its Germanic Peoples, Berkeley 2005, s. 125-127.

22 DOLEŽAL, Stanislav (ed.): JORDANES: Gótské dějiny : Římské dějiny. Praha 2012. Memoria medii aevi, XXXIV., 179, s. 77.

23 DOLEŽAL, S. (ed.): JORDANES: Gótské dějiny, XXXV., 181, s. 77.

24 MITCHELL, S.: A History, s. 150-151.

25 JONES, A. H. M.: The Later Roman Empire, 284-602: a social economic and administrative survey. Baltimore 1986, s. 192-194.
} 
Thompsona ${ }^{26}$ osudné následky i pro pozdější střetnutí na Katalaunských polích. ${ }^{27}$ Pramenné informace jsou bohužel velmi skromné. Hunové v čele s Attilou měli být zastaveni východořímskými vojsky pod vedením vojevůdce Arnegiscluse. Attilovy vojenské úspěchy byly až do bitvy na řece Utus neotřesitelné. Bitva nakonec potvrdila jeho převahu, ale padlo v ní mnoho elitních Attilových bojovníků. Pro východní rímské impérium se situace po bitvě stala kritickou. Arnegisclus v bitvě padl a východořímská armáda stála před zkázou. Attilovi se navíc podařilo vyplenit Marcianopol - hlavní město Thrákie. ${ }^{28}$ Tažení však stálo Attilu hodně. Podle Thompsona (i Alföldiho) v bitvě padla hunská vojenská elita, která mohla Hunům chybět v nadcházejícím tažení na západ.

Období tří let po velkém hunském vpádu (447) na Balkán vyplňovala diplomatická jednání mezi Huny a Rímany. Římané zůstali bez vojenských prostředků a zbývalo jim uchýlit se k diplomatickým jednáním a věřit, že Attila nebude chtít riskovat další boj. Hunové, kteří byli svým způsobem života nuceni získávat pravidelně prostředky k obživě, se obrátili k dalšímu tažení, které mělo zajistit př́ísun životních surovin k tažení proti Akatzirům. V diplomatických jednáních, která mezitím vedli východní vyslanci, vynikalo úsilí státníka Maximina. Jeho jednání jsou důležitá zejména z toho důvodu, že se jich účastnil i Priskos, který zůstává naším nejdůležitějším pramenným zdrojem informací.

Hunové si na východě postupně zajistili své pozice a bylo jen otázkou času, než Attila zaměří svoji pozornost na západ. Západní římské impérium se mohlo spolehnout na svého elitního velitele a státníka Flavia Aetia. Aetius strávil s Huny určitý čas a osvojil si jejich vojenské dovednosti. Získal tak o nich dostatečné znalosti, aby pochopil jejich vojenskou sílu, ale i slabiny. ${ }^{29}$ Vojenské přednosti ho zaujaly a v době, kdy vojenská síla římských jednotek byla v troskách, mohl využít jejich schopnosti proti nepřátelům západní římské ř́iše. ${ }^{30}$ Vedle Burgundů se musel vypořádat i s římským spojencem Vizigóty, kteří byli spíše spojencem z donucení, než že by je Římané mohli využít pro své zájmy.

$\mathrm{Z}$ pohledu dějinného vývoje, který směřoval k rozhodnému měření sil mezi Huny, Ř́many a jejich spojenci, byla důležitá osobnost vizigótského krále Theodericha I. Jeho úloha byla pro římská diplomatická jednání klíčová. Roku 418 nastoupil po Valiově vládě a výraznou měrou ovlivňoval situaci v Galii, zejména pak v její jižní části. ${ }^{31}$ Pro římské zájmy se však zpočátku jevil jako nespolehlivý spojenec.

Politická situace Ríma se stávala v průběhu první poloviny 5. století stále složitější. O to výrazněji začala vynikat úloha Flavia Aetia. Jeho úspěchy byly podmíněny (podle Buryho) velkou mírou tolerance etnických skupin, které sousedily se západní částí západního impéria. Flavius Aetius si uvědomoval vojenskou nespolehlivost gótských jednotek (i samotného Theodericha) a postupně začal využívat vojenské schopnosti Hunů proti nepokojným ř́mským sousedům.

\footnotetext{
26 Edward Arthur Thompson (1914-1994) byl britský historik působící na Notinghamské univerzitě a patří k novodobým průkopníkům zájmu o historickou oblast pozdní antiky s hlavním vědeckým zájmem o poznání života Germánů a Hunů.

27 THOMSON, A. E.: The Huns, s. 55-60.

28 JONES, A. H. M.: The Later Roman Empire, s. 192-193.

29 Podrobně se jeho osobnosti věnuje např́klad Ian Hughes. Srov. HUGHES, Ian: Aetius:Attila's Nemesis. Barnsley 2012.

30 BURY, B. J.: Later Roman Empire, s. 299.

31 WOLFRAM, Herwig: History of the Goths. Berkeley 1990, s. 170.
} 
Hunská vojska pomohla ř́mskému veliteli v boji proti Gótům v letech 437-439. K první vážnější konfrontaci, ve které se poprvé výrazněji zapojili do boje Gótové na jedné straně a Římané a Hunové na straně druhé, došlo roku 439. U Tolosy (sídelního města Theodericha I.) byli Hunové (vedeni římským vojevůdcem Litoriem) poraženi. Podle názoru Češky toto vítězství zachránilo Vizigóty před osudem, který postihl Burgundy. ${ }^{32}$ Ještě téhož roku se Aetiovi podařilo s Vizigóty obnovit mír. Aetiových diplomatických úspěchů si všímal zejména biskup Sidonius, který v něm spatřoval naději pro upadající západní impérium.

\section{Vandalové}

Z pohledu pozdějšího dějinného vývoje na Katalaunských polích se v této době udály významné události i v severní Africe. Biskup Victor z Vity uvádí velké nepokoje, které vznikly ve vandalském království. Geiserich se musel vypořádat s opozicí vandalské patricijské vrstvy. Jeho zásah byl tvrdý a odpovídal jeho válečné mentalitě. Zavedl nástupnický řád a omezil moc vandalského sněmu. Naděje pro západní impérium, že by mohlo dojít k vnitřnímu oslabení vandalského království, tak brzy pohasla.

Geiserich slavil úspěch i ve sňatkové politice, i když zatím netušil, jak velký význam budou mít následující události, které (i podle názoru například Thompsona) měly mít př́mý vliv na dějinný vývoj na Katalaunských polích. Jeho syn Hunerich (který dočasně žil na západořímském císařském dvoře jako rukojmí) byl roku 445 zasnouben s mladičkou císařovou dcerou Eudokií. Geiserich však musel nejprve zrušit Hunerichův sňatek s dcerou vizigótského krále. ${ }^{33}$ Způsob, jakým tento čin vykonal, ohromil i současníky (ve svých dílech jej zmiňují např́íklad jak Victor, tak i východořímský historik Prokopios z Kaisareie). Theoderichovu dceru obvinil z úkladné vraždy, která měla být spáchána na jeho osobě. Nechal ji proto zmrzačit uříznutím nosu a uší. V tomto stavu ji poté navrátil jejímu otci. Vztahy mezi Vizigóty a Vandaly dospěly k otevřenému neprrátelství. ${ }^{34}$ První krok k Attilově expanzi na západ byl (podle Jordana) učiněn.

Další událost, která v důsledku vedla k západnímu hunskému tažení, se stala roku 448. Přestože Aetius udržoval s Huny korektní vztahy, došlo v tomto roce k výraznému ochlazení vzájemných vztahů. Jednalo se o spor v nástupnické otázce ripuárských Franků. Aetius a Attila podpořili každý svého kandidáta. Jejich neshoda následně vedla kjejich definitivnímu odcizení.

\section{Rímský dvůr}

Attilovým motivem k tažení na západ mohlo být i jednání sestry Valentiniana III., Iusty Gracie Eudoxie. V zájmu zajištění zachování dynastického rodu Valentiniana III. byla jeho sestra jmenována titulem Augusta. V praxi to však (podle Češky) znamenalo, že se musela zavázat slibem panenství. Avšak poté, kdy vyšel najevo její vztah se správcem jejího majetku Eugeniem, nabraly události rychlý spád. Eugenius byl obviněn z uzurpace trůnu a následně popraven. Valentinianus šel ještě dále. Aniž to tušil, rozehrál pro západní impérium velmi nebezpečnou hru, ve které byla Eudoxie nucena provdat se za

\footnotetext{
32 ČEŠKA, J.: Zánik, s. 221.

33 WOLFRAM, H.: The Roman Empire, s. 165-170.

34 Tamtéž, s. 168.
} 
nepř́liš významného senátora Flavia Bassa Herculana. ${ }^{35}$ Zejména Jordanes a Prokopios zdůrazňují klíčovou událost, která dala hunskému vůdci oficiální záminku k tažení na západ: žádost Eudoxie (s pomocí eunucha Hyacintha) Attily o pomoc. Spiknutí sice bylo odhaleno (a Hyacinthus skončil na popravišti), ale Attila mohl využít oficiální nabídky, která mu otevírala cestu na západ. Eudoxie přežila, avšak byla zbavena všech hodností a provdala se za Herculana. ${ }^{36}$

\section{Hunské tažení na západ}

Attilova situace byla pro vyhlášení expanze na západ velmi příhodná, protože balkánské provincie východního impéria Hunové již vydrancovali. Hunský vládce dokonce uzavřel novou mírovou smlouvu s východořímskými vyslanci Anatoliem a Nomem. ${ }^{37}$ Východořímský císař Theodosius II. ještě roku 450 zemřel a nový císař Marcianus odmítl Attilovy požadavky. Attila se již nedal odradit od tažení na západ. Gibbon, Bury, Grant, Thompson či Alföldi se ve svých dílech (nezávisle na sobě) shodují v tom, že hlavním motivem tažení se staly bohaté galské provincie, které se jevily jako dobré řešení finanční krize (poté, kdy nový východořímský císař odmítl platit Hunům tribut). ${ }^{38}$ Závěrečné přípravy byly završeny spojením menších částí hunských kmenů pod Attilovou vládou. Pravděpodobně počítal i s tím, že při tažení bude využívat kmenů, které se dostanou pod jeho nadvládu, a jeho vojska se budou početně rozrůstat. Na počátku roku 451 vyrazilo podél Dunaje hunské vojsko spolu s kontingenty barbarských spojenců k tažení na západ. Na jaře roku 451 Attila v blízkosti dnešní Mohuče překročil Rýn. Hunská vojska začala dobývat a plenit různá severogalská města. V provincii Belgica I. Attilova vojska dobyla významné město Mettis (dnešní Mety). Je pravděpodobné, že do rukou Hunů padla i další města. Pro tuto domněnku však neexistuje dostatek důkazů. Pozornost hunského krále se však upřela k městu Aurelianum (dnešní Orleáns). Jednalo se o důležitý strategický bod, který by Hunům umožnil postup do jižní Galie. ${ }^{39}$ Sbíhaly se zde také důležité obchodní cesty a v 5. století patřilo město k nejbohatším v Galii. ${ }^{40}$

Sílu hunského náporu zaznamenal ve svých Básních Sidonius. Z jedné z nich lze vyčíst velkou obavu z hunského tažení. Popisuje „hunskou vlnu“, která hnala před sebou kmeny, které se nacházely východně od západořímské hranice: Rugijskému válečníku je po boku Gepid, za ním Gelón, Skir je tlačen Burgundem, dopředu se dere Hun, Bellonot, Neur, Bastarn, Durynk, Brukter a Frank z kraje nad Neckarem. ${ }^{41}$ Autor zde uvádí dva typy kmenů, které však sám nekategorizuje. Vedle skutečných kmenů uvádí i ty dávno zaniklé, např. Bellonoti, které Thompson přiřazuje k Ballonitům (ti však podle líčení Valeria Flaccha existovali o čtyřri století dříve). ${ }^{42}$

Mezi skutečnými kmeny, které Sidonius líčil, vynikají zejména Burgundové. Poté, kdy Burgundové prchli do Galie, část zůstala východně od Rýna. Tato skupina Burgundů

35 ČĚ̌KA, J.: Zánik, s. 223.

36 BURY, J. B.: The Invasion of Europe by the Barbarians. Norton 2000, s. 145.

37 THOMPSON, A. E.: The Huns, s. 108-111.

38 WOLFRAM, H.: The Roman Empire, s. 138-140.

39 BEDNAŘíKOVÁ, Jarmila: Attila - Hunové, Řím a Evropa. Praha 2012, s. 197-198.

40 MAN, John: Attila - barbarský král a pád Říma. Praha 2007, s. 181.

41 SIDONIUS APOLLINARIS: Carmina, Carmen VII. In Migne: P.L., 1847, Vol. 058, 341, 0687.

42 Sidonius mohl mít na mysli Ballonity, což byl „národ“ vybájený historikem Valeriem Flaccem. 
dosáhla velkého bojového úspěchu, nebot' porazili Attilova strýce Octara. Podle Sidoniova líčení lze však soudit, že Hunové při svém západním tažení uvrhli tuto část Burgundů pod svoji nadvládu.

Do jisté míry zůstává otázkou postavení Ripuárských Franků. Priskos uvádí, že dříve, než Attila zahájil tažení, pohlížel na ně jako na nepřátele. Aetius však u nich diplomaticky uspěl. Vezme-li se v úvahu Sidoniova zmínka o Neckaru (i když neexistuje přímý důkaz), je velmi nepravděpodobné, že by Attila při svém tažení nechal na svém křridle římského spojence. Nabízí se otázka, zda Attila svůj první útok směřoval právě proti Ripuárským Frankům. Podle Priska (jak uvádí Mommsen) nad nimi Attila zvítězil a část jejich bojovníků začlenil do svých vojsk.

Jak naznačují Sidonius, Thompson a Schmidt, mohlo tomu být i tak, že Attilovo vojsko překročilo Rýn nedaleko Neuwiedu. Sidonius uvádí, že Hunové porazili na říčním břehu stromy a zhotovili vory. Attila se však následně dopustil chyby, která mohla patrně pramenit z neznalosti římského práva. ${ }^{43}$ Valentinianus III. stále věřil, že hlavní hunský útok nebyl veden proti západnímu impériu, ale proti Vizigótům. Poté, co západořímský císař odmítl vydat Attilovi svoji sestru, byl konflikt mezi západní částí římské říše a Attilou nevyhnutelný. Podle římského práva Attila nemohl počítat s tím, že by případným sňatkem získal polovinu západní říše (tento fakt podporuje například Thompson). Podle historika Ióanna Malala Attila očekává od Valentiniana, aby mu připravil svůj palác. ${ }^{44}$

V této situaci se znovu projevila diplomatická a vojenská prozřetelnost Flavia Aetia. Spolu s Valentinianem dospěl k závěru, že jedinou možností je spojit se s Vizigóty. ${ }^{45}$ Aetius mohl využít „diplomatické“ chyby, které se Attila dopustil, když přijal Honoriin prsten. Tímto aktem (podle Thompsona) vedl Attila boj proti všem organizovaným armádám západní Evropy. ${ }^{46}$

Před Aetiem stál nelehký úkol - získat spojenectví Vizigótů. Vzhledem k římsko-vizigótským vztahům se jevilo jako nepravděpodobné, že by Aetius vyjednal s Theodorichem I. spojenectví. Jejich vzájemné rozpory byly prŕliš velké, než aby mohli vést oboustranná úspěšná jednání. Bylo nutné hledat jiné řešení, které nakonec padlo na budoucího císaře Avita. Avitovy činy a veliké vladařské schopnosti jsou často zmiňovány jeho tchánem, biskupem Sidoniem. Avitus byl ravennskou vládou vybrán pravděpodobně z důvodu svých diplomatických úspěchů poté, když roku 439 uzavřel pro Řím s Theodorichem I. mír.

Spojenectví západního impéria a Vizigótů se stávalo nezbytností. Kdyby $\mathrm{k}$ němu nedošlo, bylo pravděpodobné, že Theodorich I. by bránil pouze své království s centrem v Toulouse. Aetius však potřeboval rozšíríit své síly i na sever a postavit se tak Attilovi co nejblíže k hranicím.

Podle Sidonia však byla situace (z pohledu ravennské vlády) kritická. V Carmen VII. zdůrazňuje, že když Aetius opouštěl Alpy s nevelkým a slabým vojskem, Attilovy jednotky byly již rozprostřeny po galských pláních. ${ }^{47}$

Aetius mezitím musel řešit další problém. Území Itálie bylo v této době sužováno velkým hladomorem a morálka jeho vojáků byla otřesena. Podle Jordana se Aetiovo vojsko

43 THOMPSON, A. E.: The Huns, s. 137-140.

44 Tamtéž, s. 138-139.

45 GRANT, Michael: The Fall of the Roman Empire. London 2005, s. 99-100.

46 THOMPSON, A. E.: The Huns, s. 139-140.

47 SIDONIUS APOLLINARIS: Carmina. 
skládalo především z pomocných jednotek. Tento stav prokazatelně snižoval vojenskou sílu rrímské armády. Přestože se nakonec v dubnu či v květnu 451 spojil s Theodorichovými Vizigóty, byla vojenská síla všech jeho jednotek přinejmenším nesourodým celkem. Nová koalice přinutila Attilova vojska upustit od obléhání Aureliana a obrátit se zpět na sever, kde se však nacházela popleněná města a Hunům reálně hrozila vážná zásobovací krize. ${ }^{48}$

V Jordanově Getice lze vyčíst soupis kmenů, které tvořily jádro Aetiovy armády. ${ }^{49}$ Zvláštní postavení měli Burgundové. Jak bylo uvedeno, Burgundové byli rozděleni na dvě skupiny. Vznikla tak zvláštní situace. Část Burgundů, která byla poražena Aetiem, jenž proti nim v minulosti použil hunské spojence (a po jejich porážce je usadil v Savojsku), bojovala nyní na římské straně. Druhá část Burgundů, která byla pod Attilovou mocí, směřovala s jeho vojskem proti Římu. ${ }^{50}$

Jordanes uvádí ještě dva kmeny, o kterých se jiné prameny nezmiňují: Liticiani a Olibrioni. Na straně Rímanů jsou také jmenováni Ripuárští Frankové, z nichž mnozí stihli před Attilou prchnout. Lze soudit, že se k vojsku přidalo i určité množství Sálských Franků, kteří již byli (více než půl století) usazeni na území říše. Bez zajímavosti není ani Jordanova informace o Sasech. Podle Buryho je možné, že v této době již založili severně od Loiry několik sídel a byli ravennskou vládou akceptováni. ${ }^{51}$ Jak připomínal ve svém díle (o několik desetiletí dříve) již Ammianus Marcellinus, sasko-římské vztahy nebyly v žádném případě ideální. Ř́mané Sasy opovrhovali a jejich expanze do Británie, jistě nepřispěla k upevnění přátelských vztahů. Hunská expanze na západ však představovala pro obě strany velké nebezpečí, zvláště pak pro Sasy. Těm by reálně hrozilo (v př́ípadě Attilova vítězství) podmanění. I když vztahy s Římany nebyly ideální, Sasové se rozhodli zvolit menší zlo.

Nezodpovězenou otázkou zůstává postavení Armoričanů. Podle Sidonia se měli zúčastnit v Aetiově vojsku tažení proti Hunům. Jak však mohlo dojít k tomu, že se rozhodli bojovat za svého dávného nepřítele? Zůstává nám pouze Sidoniovo svědectví. Podle něj byli vybídnuti Sidoniovým tchánem Avitem. Ale pro tuto interpretaci není v jiných pramenech žádný důkaz.

Jordanes připomíná i Sarmaty. Jejich postavení také zůstává záhadou. Pravděpodobně autor míní Alany, jejichž chování bylo „dvojznačné“. Podle autora nejprve stáli na Aetiově straně. Avšak alanský král Sangiban (v obavě z budoucích událostí) slíbil poddat se Attilovi a předat mu Aurelianii, kde právě sídlil, a připojit se k Attilově tažení proti Vizigótům. Aetius se však dozvěděl o jeho úmyslech a dal město obsadit svými vojsky. Hunové ale mezitím město oblehli. ${ }^{52}$

Podle legendy, kterou uvádí ve svém díle Řehoř z Tours, měl biskup sv. Anianus přesvědčovat obyvatele města, aby nepouštěli Attilovo vojsko do města. V tu chvíli se objevily jezdecké oddíly Ř́manů a Vizigótů..$^{53}$ I podle Sidonia byl Attila natolik překvapen jejich spojenectvím, že upustil od dobývání a s vojskem se stáhl.

Po potyčkách na Marně ustoupil raději k Mauricijským (Katalaunským) polím. Jednalo se o rovinu někde mezi dnešními městy Chalôns-sur-Marne a Troyes, místo zvané

\footnotetext{
48 BEDNAŘíKOVÁ, J.: Attila, s. 198.

49 DOLEŽAL, S. (ed.): JORDANES: Gótské dějiny, XXXVI., 191, s. 79.

50 BURY, B. J.: Later Roman Empire, s. 254-260.

51 Tamtéž, s. 256-260.

52 DOLEŽAL, S. (ed.): JORDANES: Gótské dějiny, XXXVII., s. 80.

53 BEDNAŘÍKOVÁ, Jarmila: Stěhování národů. Praha 2003, s. 66.
} 
Campi Mauriaci nebo Campi Catalaunici, kde se nacházel jen jediný kopec. ${ }^{54}$ Man však upozorňuje, že Chalôns ve skutečnosti leží asi o 50 kilometrů dále na sever. Blízko se však mělo nacházet místo Mauriacum, které odpovídá dnešnímu městu Méry-sur-Seine nacházejícímu se pouhé tři kilometry od Chârtres. ${ }^{55}$

\section{Bitva}

Podle Buryho zatím nelze přesně určit území, kde se uváděné místo nacházelo, ${ }^{56}$ ale nejvíce teorií se přiklání k prostoru právě nedaleko Troyes. Můžeme předpokládat, že Attilovi mohlo více vyhovovat střetnout se s Aetiovými vojsky na otevřené pláni, kde mohl využít svých elitních hunských jízdních vojsk. Podle Doležala tomu však mohlo být i jinak. Římská armáda využívala (již od doby vlády Valenta) vynikající jízdní lučištníky, ${ }^{57}$ kteří mohli být rovnocennou konkurencí hunským protějškům. V této situaci došlo k rozhodujícímu střetnutí známému v historii jako bitva na Katalaunských polích. Přesné datum bitvy je nejasné. Podle Buryho k ní došlo 20. června 451. ${ }^{58}$

Podle Jordana mělo dojít ještě den před bitvou k boji mezi Aetiovými Franky a Gepidy. Ztráty v tomto střetnutí činily celkem 15000 mužů..$^{59}$ Žádný jiný pramen však autorovo tvrzení nepotvrzuje. Attila se (podle Jordana) rozhodl, uchýlit se nejprve k věštbám, které měly potvrdit jeho vítězství. Obě vojska stála proti sobě již v devět hodin ráno. Údajně proto, aby se Attila mohl navečer skrýt ve tmě, kdyby se boj nevyvíjel v hunský prospěch.

Boj začal o blízký vrch. Jeho získání mělo mít pro bitvu rozhodující strategický význam. Střetnutí však zůstalo nerozhodné a vrch neobsadilo žádné z vojsk. Každá z bojujících stran získala pouze část stráně.

V době bojů o vrch se pod kopcem shromáždila obě hlavní vojska. Aetiovo vojsko se dělilo do třech hlavních skupin. Pravé křídlo tvořili Theoderichovi Gótové. Aetius se svým „ř́mským“ vojskem byl na levém křídle bojové sestavy. Pojistil si Sangibana a Alany tím, že je umístil mezi Góty a Rímany. Jak uvádí Jordanes: pokud by Sangiban chtěl ustoupit, neměl by kam. ${ }^{60}$ Attila s jádrem svého vojska stál uprostřed. Zůstává otázkou, zda počítal se Sangibanovou liknavostí, která mohla mít pro výsledek bitvy zásadní význam. Jeho pravé i levé křídlo sestávalo z vojsk porobených národů.

A tak stáli proti sobě Gepidové a Ostrogóti na jedné straně a Gótové proti nim na straně druhé. Na straně Hunů vynikalo vojsko Ostrogótů vedené bratry Valamirem, Thiudimerem a Vidimerem. Jordanes vyzdvihuje i úlohu Ardarica, ${ }^{61}$ který byl údajně věrný Attilovi. Vynikal spolehlivostí a rozvahou a dokonce se měl aktivně zúčastňovat jeho válečných porad.

Začátek bitvy nebyl pro Huny př́znivý, nebot při něm ztratili již dobytou část kopce. Bitva však pokračovala dále. Během boje padl Theoderich, který zahynul v důsledku sražení z koně a následně byl koňmi ušlapán. Podle Jordana mohl Theoderich zemřít i na

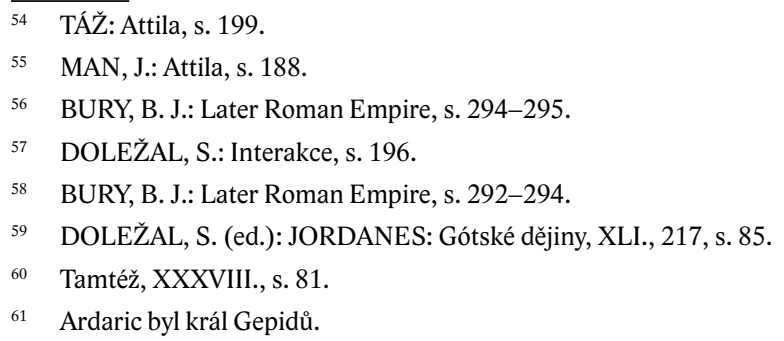


zranění způsobené kopím, které po něm vrhl Andagis z kmene Ostrogótů. ${ }^{62} \mathrm{~V}$ průběhu boje však o smrti vizigótského krále jeho muži zatím nevěděli. Bitva trvala až do večerních hodin a klid zbraní nadešel až se soumrakem. Ztráty na obou stranách byly velké. Jordanes uvádí pravděpodobně vysoce nadsazené číslo 165000 padlých. ${ }^{63}$ Ale i tak byl počet padlých nevídaně vysoký.

Určit přesný výsledek bitvy uplynulého dne není jednoduché. Attila se uchýlil se soumrakem pod kruhovou vozovou hradbu a na jejím obvodu nechal postavit lučištníky. Tím se stalo jeho ležení téměř nedobytné. Aetius však neměl dostatek sil, aby svého nepřítele s konečnou platností porazil. Mohlo se však jednat i o jeho prozíravost, nebot' následujícího dne se stala zvláštní událost.

Vizigóti nalezli mezi mrtvými bojovníky i Theodericha a jejich hněv se soustředil na pomstu. Rozhodli se zničit Attilu obklíčením a následným vyhladověním. Jednalo se o vhodný taktický tah, nebot' Attilova vojska byla obklíčena. I když hunští lučištníci představovali pro útočníky smrtelné nebezpečí, stačilo by Aetiovi a Vizigótům pouze čekat. Jordanes zaznamenal Attilovo chování a vyzdvihuje jeho statečnost. Uvádí, že než by kapituloval, raději by se nechal královsky obřadně spálit. ${ }^{64}$

Další den Aetius provedl nečekaný tah. Podle Thompsona ${ }^{65}$ nebyli Hunové nikdy skutečnými nepřáteli Aetia. Pokud by Vizigóti zaútočili plnou silou na Attilu, lze předpokládat, že by útok byl úspěšný. Vizigóti by poté získali dominantní postavení na území západní římské říše. Aby tomuto nebezpečí Aetius zabránil, přemluvil Thorismunda, aby se vrátil do Toulouse a nedovolil svým bratrům zmocnit se trůnu po otci. ${ }^{66}$ Aetius postupoval stejným způsobem i u mladého franského panovníka. Podle Thompsona se snad mohlo jednat o Chlogia nebo Merovecha. ${ }^{67} \mathrm{I}$ v tomto prŕṕpadě Aetius dokázal svoji vůli prosadit diplomaticky.

\section{Výsledek bitvy}

Bitva na Katalaunských polích skončila nerozhodně. Je pravděpodobné, že by však nemusela. Aetiova vojenská převaha sil, vojenské umění a výběr spojenců se ukázaly být silnější než Attilovy. Attila prorazil obklíčení a jeho hněv se obrátil jak na východní, tak i na západní impérium.

Na východ vyslal menší skupinu Hunů, která vyplenila východní Illyricum. Připomněl tím východořímskému císaři obnovení tributu, který císař Hunům zastavil. Na západě (v květnu 452) Attila oblehl Aquileu. Město odolávalo tři měsíce hunskému náporu, až Attila prolomil hradby a obyvatelstvo zmasakroval. ${ }^{68}$ Aetiův plán nevyšel. Podle Jordana, sílila u Hunů touha po ř́mské krvi. Hunové následně šírili zkázu i v dalších městech Venetie. ${ }^{69}$ Až složitým vyjednáváním se podařilo Attilu přesvědčit, aby severní Itálii

62 DOLEŽAL, S. (ed.): JORDANES: Gótské dějiny, XL., s. 83.

63 Tamtéž, XLI., 217, s. 85.

64 Tamtéž, XL., 213, s. 84.

65 THOMPSON, A. E.: The Huns, s. 73-75.

66 Podrobně bitvu také analyzuje např. MacDowall, který si všímá zejména vojensko-taktické stránky střetnutí. Srov. MACDOWALL, Simon: Catalaunian Fields AD 451 : Rome's last great battle. Oxford 2015.

67 THOMPSON, A. E.: The Huns, s. 75.

68 BEDNAŘíKOVÁ, J.: Stěhování národů, s. 68.

69 DOLEŽAL, S. (ed.): JORDANES: Gótské dějiny, XLII., s. 86. 
opustil. ${ }^{70}$ Aetiův postoj k Attilovi zůstává nejasný. Jordanes jeho činy (související s touto situací) blíže neanalyzuje. Sidonius posuzoval Aetia jako velkého Rímana a zachránce římského impéria. Ale na Katalaunských polích měla jeho obojakost vůči Gótům a Hunům na západní impérium negativní dopad. Attila nejen nepochopil Aetiovo gesto, kterým jej (a tím i Huny) zachránil takřka před jistou smrtí, ale naopak si vyložil chování římského vojevůdce jako slabost svých nepřátel. Věřil, že Vizigóti se odtrhli od Římanů a jejich spojenectví je v troskách.

Můžeme předpokládat, že právě tento pocit ho utvrdil v tažení proti severoitalským městům. Avšak současníci pojímali tuto situaci jinak. Aetiova moc po bitvě vrcholila. Jeho moc i vliv jej nakonec roku 454 také stály život. Eunuch Heraclius přesvědčil Valentiniana III., že připravovaný sňatek Aetiova syna Gaudentia a princezny Placidie má za cíl svrhnout císaře $\mathrm{z}$ trůnu. ${ }^{71}$ Rok před touto událostí zemřel také Attila. V průběhu první poloviny 50. let 5. století tak zemřeli hlavní účastníci střetnutí na Katalaunských polích: Theoderich (padl prímo na bojišti), Attila (zemřel pravděpodobně na mor v Panonii), Aetius (jako poslední mohl výrazněji ovlivnit dějiny rozpadajícího západořímského impéria).

\section{Závěr}

Zhodnotit bitvu na Katalaunských polích je složité. V zásadě existují dva základní pohledy. Češka hodnotí bitvu jako nerozhodnou a uvádí, že Aetius sice dosáhl taktického (nikoliv strategického) vítězství, ale nedokázal ho plně využít. ${ }^{72}$ Podobný názor sdílí i Thompson. ${ }^{73}$ Naopak Bury považuje význam této bitvy za přeceňovaný, protože bitva ve skutečnosti nevyřešila nic podstatného. ${ }^{74}$

Na Katalaunských polích byla zadržena útočná „vlna“ Hunů a Attila zde utrpěl velké ztráty, které mohly být ještě podstatnější nebýt Aetiova zásahu. Výsledek bitvy se proto může jevit jako nerozhodný. Lze však konstatovat, že Attila utrpěl první taktickou porážku a mýtus o jeho neporazitelnosti začal upadat. Podle Bednaříkové proto, že jeho pověst na Katalaunských polích utrpěla, zorganizoval vojenské tažení do severní Itálie, aby opět demonstroval svoji sílu. To se mu také do určité míry podařilo. ${ }^{75}$

Hodnotit bitvu $\mathrm{z}$ římského pohledu je složité. Z taktického hlediska byl nepochybným vítězem Aetius. Přesto, jak poukazuje Doležal, bez podpory federátů (zejména Vizigótů) by sami Ř́mané pravděpodobně Hunům podlehli. ${ }^{76}$ Svým způsobem dokázal nepřímo zvítězit i nad svými spojenci, kdy se obratně zbavil jak Vizigótů, tak Franků.

Hodnocení bitvy z pohledu Germánů je ještě složitější. Po Attilově smrti se jeho hunský kmenový svaz postupně rozpadal. Tento proces pak vyvrcholil v polovině 50 . let 5 . století. Důkazem může být bitva na řece Nedao, kdy se proti Hunům postavily porobené národy vedené východogermánskými Gepidy (v čele s Ardarichem). Hunům sice pomohli Ostrogóti, ale obě etnika v bitvě prohrála. Ostrogóti se poté odtrhli, a i když se Hunové

71 ČEŠKA, J.: Zánik, s. 225.

72 Tamtéž, s. 224.

73 THOMPSON, A. E.: The Huns, s. 150-153.

74 BURY, B. J.: Later Roman Empire, s. 295-297.

75 BEDNAŘíKOVÁ, J.: Stěhování národů, s. 69.

76 DOLEŽAL, S.: Interakce, s. 302. 
pokoušeli nad nimi obnovit moc, na konci 60 . let 5 . století byli bývalými ostrogótskými spojenci poraženi.

Mocenského vakua postupně začali využívat zejména Vandalové. Po zavraždění Aetia ho brzy následoval i poslední představitel Valentinianovské dynastie v západním impériu Valentinianus III. Vůdce povstání Petronius Maximus se prohlásil císařem a donutil k sňatku Valentinianovu manželku Eudoxii. Ta se obrátila o pomoc na Geisericha a roku 455 následovalo druhé vyplenění Říma. Vandalský král vyčkal př́ihodné doby, kdy budou všichni jeho nepřátelé oslabeni, a tato skutečnost mu následně umožnila stát se největším vítězem událostí 50 . let 5 . století a dodatečným vítězem bitvy na Katalaunských polích.

Moc dalších germánských kmenů po bitvě také stoupla. Vizigóti se stále více prosazovali ve východní části Hispánie, Svébové kontrolovali její západní část. Úspěch zaznamenali i Burgundové, když se zmocnili Lugduna a jeho okolí. Územního rozšśření dosáhli i Frankové a Alamani, kteří se zmocnili dalších oblastí západně od Rýna. Sasové, kteří se také účastnili bitvy, si upevnili moc v Británii. ${ }^{77}$

Mocenská rovnováha, která existovala v prvních desetiletích 5. století, se stala minulostí. Evropa se musela z velké části postavit novým podmínkám, jejichž podstatnou část tvořily nově se formující státní útvary - království Franků, Burgundů, Vizigótů aj.

\section{Summary}

\section{Catalaunian plains not only by contemporary authors}

The presented text describes the Battle of the Catalaunian Plains and the situation in late ancient Europe from the perspective of selected Roman authors and contemporary historians. Their views agree on some points and not on others. There are basically two views. Some historians think that the outcome of the battle was undecided. The Romans won the battle, but could not take advantage of the victory. The second group of historians believes that the battle had not solved anything signifcant. Romans also allowed the Hun leader to escape the battle, and this meant great complications for the Romans, especially in the future. Evaluating the battle from a Roman perspective is difficult. The Romans won the battle and managed to partially weaken the influence of Germanic allies for a short time. But the murder of Aetius in 454 greatly weakened the Roman power in the west. The culmination of the decline of Roman power a year later was the destruction of Rome by Vandals. It is also important to stress that the Romans would not win over the Huns without Germanic help. Without the help of the Germanic peoples, the outcome of the battle would probably have ended in a great defeat for the Western Roman Empire. We can say that the importance of the battle lies in the fact that it was the last major military victory of the Western Roman Empire.

77 PEROWNE, Stewart: The End of the Roman World. Michigan 1966, s. 82-87. 